\title{
Effect of Urea Treated Groundnut Shells on Feed Intake, Digestibility, Nitrogen Retention and Economic Value in Growing Rabbits
}

Muhammad Tahir Khan ${ }^{1}$, Muhammad Idrees Khan ${ }^{1}$, Sayed Haider Abbas Raza ${ }^{2 *}$, Muhammad

Adnan $^{5}$, Rajwali Khan ${ }^{2}$, Seyed Mahdi Hosseini ${ }^{3}$,Shahid Faraz Syed ${ }^{4}$, Shahzada Khurram Adrian shah $^{5}$, Muhammad Atif Khan ${ }^{4}$, Abrar Ahmad ${ }^{4}$

${ }^{1}$ Faculty of Animal Husbandry \& Veterinary Sciences, The University of Agricultural Peshawar 25000 Pakistan

${ }^{2}$ College of Animal Sciencesand Technology, Northwest A \& F University, Yangling 712100, China.

${ }^{3}$ College of Animal Science and Technology, Huazhong Agricultural University, Wuhan, China

${ }^{4}$ Faculty of Animal Husbandry and Veterinary Sciences Sindh Agriculture University, Tandojam

${ }^{5}$ Khyber Institute of Veterinary Sciences Peshawar25000 Pakistan

Received: February 06, 2017; Accepted: March 15, 2017; Published: April 27, 2017

*Corresponding author: Sayed Haider Abbas Raza, College of Animal Sciences, Northwest A \& F University, Yang ling 712100, China, E-mail: dr.haiderabbasraza@gmail.com

\begin{abstract}
The experiment of the current study was performed at Rabbitry of Poultry Science Department and the chemical analysis was carried out at Department of Animal Nutrition, Faculty of Animal Husbandry and veterinary sciences, The University of Agriculture, Peshawar. The recent study examines the effect of different level of Urea (UR) and Soybean Meal (SBM) treated groundnut shells on rabbit's performance and economic evaluation of the experimental diet. A total of sixteen male local black and white rabbit's of Mini Rex breed weaning age $35+5$ of having body weight range from 1065$1170 \mathrm{~g}$ were selected at random to four treatments, with each treatment diet for four rabbit's. Metabolic cages were provided for each group of rabbits with separate facility for the feces and urine collection. Four diet's were formulated for the current experiment which contain $0 \%$ urea treated groundnut shells (UR-0\%), 1\%urea treated groundnut shells (UR-1\%), $2 \%$ urea treated groundnut shells(UR-2\%) and $2 \%$ urea $+2 \%$ soybean meal treated groundnut shells (UR-2\% +SBM-2\%)respectively. The soybean meal was used as urease source. The formulated diets were tasted for 56 days. The present result showed that the feed intake in group D containing urea and SBM treated groundnut shells were significantly higher than the experimental diet A, B and C. The digestibility coefficient of dry matter (70.91) organic matter (78.89), crude protein (80.63), ash (73.96), NDF (72.12), ADF (58.13) and ADL (42.10) were more significant $(\mathrm{p}<0.05)$ in experimental diet $\mathrm{D}$ as compare to $\mathrm{B}, \mathrm{C}$ and control group. The enhancement in feed intake and nutrient digestibility may be due to the addition of SBM as urease source which increase the urea hydrolyzation. The nitrogen retention was significantly higher in experimental diet $\mathrm{B}, \mathrm{C}$ and $\mathrm{D}$ as compare to control one. The highest value of retained nitrogen (2.00) was observed in experimental diet D. The average body weight gain (5.12) and feed conversion ratio (3.11) were significantly improved for group of rabbit's fed by diet D than the experimental diet A, B and C. Maximum profitability was observed in experimental diet D (Rs. 63.92) and was followed by experimental diet C, B and control one. From the present experiment it was concluded that the use of different level of urea and soybean meal treated groundnut shells increased the feed intake, nutrient digestibility, retention of nitrogen and body weight gain in experimental animals.
\end{abstract}

Keywords: Groundnut shells; Urea; Soybean meal; Rabbit; Digestibility;

\section{Introduction}

By increase in human population the demand for food has been deeply inclined. The animal protein availability for human utilization is not enough to fill the gap among need and supply. Because of high price of meat which gone away from the public reach, the accessibility of small quantity of animal protein for human utilization in developing countries disturbing the health and safety of the increasing population. [1].

Rabbit's are small mammals belong to Leporidae family and order Lagomorphs. Rabbit's have many characteristics, due to which it become an excellent source for meat production in developing countries, e.g. small body size, rapid growth rate, short generation interval, small gestation period, high prolificacy, genetic diversity, and short involution period [2].

The exchange of the country abundant crop residues into nutritive feed ingredients would be highly advantageous from several standpoints e.g. maximization of bio resource utilization, appropriate waste disposal and sustainable animal production [3]. Various studies had confirmed the presence of cellulolytic bacteria in the distal part of the small intestine and in the ceacum of Rabbit's [4].

Therefore, monogastrics animal have the ability to utilize cellulose, a major constituent of crop residues. To utilize the crop residues as non ruminants feed ingredients would 
require prior chemical or biological treatment to break the strong association between structural polysaccharides and lignin which restricts the enzymatic degradations of cellulose [5].

This practice of feeding low energy high fiber diet for growing rabbit's as a way to reduce digestive disorders has greatly weakened the overall farm feed efficiency [6]. On opposing, increasing high digestible fiber fractions, such as hemicelluloses and especially pectin's, may motivate caecal fermentation transform the micro biota composition positively affect intestinal mucosa integrity and decrease the death rate caused by diarrhea [7].

Groundnut (Arachis hypogea) is the most important legume and belongs to legume or bean family (Fabaceae) specie. Recent advances in rabbit nutrition research have increased the number of criteria that are part of the nutritional recommendations, especially in the area of fibrous components $[8,9]$.

Groundnut shell is a byproduct of groundnut processing industry. Groundnut shell is obtained when the nut is being removed for consumption by removing the shell manually or mechanically. The shell, though sometimes heaped and burnt, do usually just left lying around in unsightly, smelly heaps, rotting, thus make up an environmental pollution trouble. For now, because being a waste, groundnut shells could be very cheap, because the only cost would be the collection, treatment and transport to the site. Exploiting cheap feed resources for livestock production would lower the price in the market, thus increasing the intake of animal protein by the public in underdeveloped countries [10].

Therefore, the objective of the present study was to evaluate the effect of different level of urea treated groundnut shells with or without the addition of Soybean Meal (SBM) as a source of urease on feed intake, digestibility, nitrogen retention and economic value in growing rabbits.

\section{Materials and Method}

\section{Animals and management}

The experiments of the present study were carried out at the Rabbitry of Poultry Science Department, and chemical analysis was carried out in the laboratories of Department of Animal Nutrition, Faculty of Animal Husbandry and Veterinary Sciences, The University of Agriculture, Peshawar Pakistan. Four experimental diets were formulated containing different level of urea (UR) and soybean meal (SBM) treated groundnut shells to determine its effect on the performance of growing rabbits as shown in table 1. Sixteen male rabbit's of Mini Rex breed weaning age $35+5$ having body weight range from 1065-1170g were selected at random to four treatments, with each treatment diet for four rabbit's. Prior the experiment to be started cleaned the cages and the other equipments such as buckets, feeders and drinkers.

\begin{tabular}{|c|c|c|c|c|}
\hline \multicolumn{6}{|c|}{ Table 1: Formulation of the Experimental Diet's (in gm). } \\
\hline Ingredients & UR-0 & UR-1 & UR-2 & UR-2+SBM-2 \\
\hline Groundnut Shells & 25 & 25 & 25 & 25 \\
\hline Maize & 12 & 15 & 18 & 22 \\
\hline Wheat Bran & 12 & 12 & 13 & 12 \\
\hline Berseem Hay & 7 & 6 & 7 & 7 \\
\hline $\begin{array}{c}\text { Mustard seed } \\
\text { cake }\end{array}$ & 18 & 16 & 14 & 13 \\
\hline Sunflower Cake & 18 & 17 & 14 & 13 \\
\hline Molasses & 7 & 8 & 8 & 7 \\
\hline Salt & 0.5 & 0.5 & 0.5 & 0.5 \\
\hline Vitamin/mineral & 0.5 & 0.5 & 0.5 & 0.5 \\
\hline \begin{tabular}{c} 
Total \\
\hline
\end{tabular} & 100 & 100 & 100 & 100 \\
\hline
\end{tabular}

\section{Groundnut shells processing}

From the local groundnut processing markets the dried groundnut shells were brought in large bales. Then make four groups from groundnut shells divided equally. One group maintain controlled (UR-0\%) having the chemical composition as shown in table 2 and the remaining three groups were treated with an appropriate solution made up of $1 \%$ graded urea (UR$1 \%$ ), $2 \%$ graded urea (UR-2\%) and $2 \%$ graded urea $+2 \%$ soybean meal (UR-2\% + SBM-2\%) as urease source $(w / w)$.

\begin{tabular}{|c|c|c|c|c|c|c|c|c|}
\hline \multicolumn{1}{|c|}{ Table 2: Chemical Composition of Groundnut shells (\%DM Basis). } \\
\hline $\begin{array}{c}\text { D.M } \\
\text { (as fed) }\end{array}$ & C.P & C.F & NDF & ADF & Lignin & E.E & Ash & $\begin{array}{c}\text { Gross Energy } \\
\text { MJ/kg DM }\end{array}$ \\
\hline 91.0 & 6.9 & 64.0 & 69.2 & 59.9 & 23.5 & 2.0 & 5.3 & 19.7 \\
\hline
\end{tabular}

The treated groundnut shells were left over in anaerobic condition in large polythene sheets for two weeks. During this period intense care was taken to prevent escape of ammonia gas produce after urea and water reaction. After two weeks, the treated groundnut shells were removed and were sun dried for three days. For making the homogenous pellet diet, both the nontreated and treated groundnut shells were ground to powder form to pass a two mm screen.

\section{Feeds and feeding}

All the animals were supplied with 200 gm pelleted experimental feed every day. The animals of group A received diet containing $0 \%$ urea treated groundnut shells, group B $1 \%$ urea treated groundnut shells, group C $2 \%$ urea treated groundnut shells and group D 2\% urea + 2\% soybean meal treated groundnut shells respectively. The daily feed intake was determined by subtracting the remaining feed from the total feed offered. The obtaining data was used to determine the feed conversion 
ratio and daily weight gain. Clean and fresh drinking water was offered twice a day to all animals individually. To determine the body weight gain, the final body weight was subtracted from the initial body weight of the rabbit. The feed conversion ratio was determined by comparing the total amount of feed consumed by the overall gain in body weight, as measured efficiency of feed used.

\section{Digestibility Trial}

At the middle of the experiment the metabolic trial was performed and continues for five days. Metabolic cages were provided for each group of rabbits with separate facility for the feces and urine collection. During the five days collection period, the offered feed, unconsumed feed, urine voided and feces voided were calculated daily. Take the weight of total feces voided and dried in oven until to achieve the constant weight at $65^{\circ} \mathrm{C}$. After drying the feces were ground for chemical analysis. Measure the collected urine and then mixed with weak hydrochloric acid to prevent the nitrogen evaporation from urine. The retention of nitrogen (gm/day) was determined by subtracting the total excreted nitrogen in urine and feces (gm/day) from the total nitrogen (gm/day) consumed in diet by the rabbits. Before and after the feeding trial the weight of growing rabbits were taken to determine the growth and feeding level during metabolic trial.

\section{Chemical Analysis of feed and feces}

Representative samples from feed and feces were taken and were ground having the size of one mili meter. The grounded sample was analyzed according to the method of AOAC (2007) for determination of proximate components e.g. dry matter (DM), crude protein (CP), crude fiber (CF), ash, ether extract (EE) and nitrogen free extract (NFE) as shown in table 3 [11]. Neutral detergent fiber (NDF), acid detergent fiber (ADF) and acid detergent legnine (ADL) were determined with the procedure of Van Soest $[12,13]$.

\begin{tabular}{|c|c|c|c|c|c|c|c|c|}
\hline \multicolumn{2}{|c|}{ Table 3: Chemical composition of the experimental diet } \\
\hline Diets & DM\% & CP\% & OM\% & EE\% & Ash\% & NFE $\%$ & CF $\%$ & TDN\% \\
\hline UR- 0\% & 92.85 & 15.80 & 84.78 & 14.83 & 8.07 & 6.420 & 44.96 & 65.96 \\
\hline UR- 1\% & 92.34 & 15.93 & 83.59 & 15.27 & 8.75 & 6.576 & 44.98 & 66.38 \\
\hline UR- 2\% & 92.89 & 16.02 & 84.76 & 14.64 & 8.13 & 9.271 & 43.65 & 66.33 \\
\hline $\begin{array}{c}\text { UR-2\% } \\
\text { +SBM2\% }\end{array}$ & 92.84 & 15.96 & 84.51 & 17.11 & 8.33 & 9.497 & 41.66 & 66.56 \\
\hline
\end{tabular}

\section{Economic}

The price of pet rabbit feed consumed was determined and the each rabbit profit was calculated by subtracting per rabbit feed cost from total sale of rabbit's of every group.

\section{Statistical Analysis}

In MS excel, the data was assembled and was statistically analyzed through SPSS program window. 16 Version. To compare the means of different studied variables, complete randomized design was used. The least significant difference test was used to determined significant differences among the effects of experimental diets.

\section{Result and Discussion}

\section{Feed intake}

The mean values of the dry matter, organic matter and crude protein intake are described in the table 3.1. The experimental ration A, B, C and D means values of DMI were 57.12, 59.88, 67.06 and 72.66 (gm/day) respectively. The dry matter intake of rabbits receiving ration $\mathrm{B}, \mathrm{C}$ and $\mathrm{D}$ were significant $\mathrm{P}<$ 0.05 ) from each other. However the DMI of the groups of rabbits feeding rations $\mathrm{A}$ and $\mathrm{B}$ were non significant. The dry matter intake of the ration $\mathrm{D}(72.66 \mathrm{~g} / \mathrm{d})$ was maximum among the four tested rations.

Table 3.1: Effect of urea and SBM treated Groundnut shells on daily feed intake (Mean $+\mathrm{SE}$ ) in growing rabbit's

\begin{tabular}{|c|c|c|c|c|}
\hline \multirow{3}{*}{$\begin{array}{c}\text { Feed } \\
\text { intake(gm/ } \\
\text { day) }\end{array}$} & \multicolumn{4}{|c|}{ Diets } \\
\hline & $\mathbf{A}$ & B & C & D \\
\hline & UR-0\% & UR-1\% & UR-2\% & $\begin{array}{c}\text { UR-2\% + SBM } \\
2 \%\end{array}$ \\
\hline DMI & $\begin{array}{c}57.12^{\mathrm{c}} \pm \\
1.482\end{array}$ & $\begin{array}{c}59.88^{\mathrm{c}} \pm \\
1.439\end{array}$ & $\begin{array}{c}67.06^{\mathrm{b}} \pm \\
1.608\end{array}$ & $72.66^{\mathrm{a}} \pm 1.271$ \\
\hline OMI & $\begin{array}{c}50.7^{\mathrm{c}} \pm \\
1.597\end{array}$ & $52.7^{\mathrm{c}} \pm 0.935$ & $\begin{array}{c}57.7^{\mathrm{b}} \pm \\
0.796\end{array}$ & $63.1^{\mathrm{a}} \pm 1.201$ \\
\hline CPI & $\begin{array}{l}4.95^{c} \pm \\
0.630\end{array}$ & $\begin{array}{c}6.91^{\mathrm{bc}} \pm \\
0.664\end{array}$ & $\begin{array}{c}8.87^{\mathrm{b}} \pm \\
0.616\end{array}$ & $13.14^{\mathrm{a}} \pm 0.772$ \\
\hline EEI & $\begin{array}{c}9.79^{\mathrm{b}} \pm \\
0.687\end{array}$ & $\begin{array}{c}10.00^{\mathrm{b}} \pm \\
0.600\end{array}$ & $\begin{array}{c}9.81^{\mathrm{b}} \pm \\
0.661\end{array}$ & $12.77^{\mathrm{a}} \pm 0.779$ \\
\hline NFEI & $\begin{array}{c}4.50^{c} \pm \\
0.912\end{array}$ & $\begin{array}{c}6.44^{\mathrm{bc}} \pm \\
0.936\end{array}$ & $\begin{array}{c}7.80^{\mathrm{b}} \pm \\
0.505\end{array}$ & $11.143^{\mathrm{a}} \pm 0.912$ \\
\hline Ash I & $\begin{array}{c}3.87^{c} \pm \\
0.646\end{array}$ & $\begin{array}{c}6.66^{\mathrm{b}} \pm \\
0.858\end{array}$ & $\begin{array}{c}8.58^{\mathrm{b}} \pm \\
0.955\end{array}$ & $10.97^{\mathrm{a}} \pm 0.443$ \\
\hline NDFI & $\begin{array}{l}41.44^{\mathrm{d}} \pm \\
1.336\end{array}$ & $\begin{array}{c}47.64^{\mathrm{c}} \pm \\
0.878\end{array}$ & $\begin{array}{c}53.82^{\mathrm{b}} \pm \\
1.476\end{array}$ & $64.87^{\mathrm{a}} \pm 1.013$ \\
\hline ADFI & $\begin{array}{c}27.37^{\mathrm{d}} \pm \\
1.193\end{array}$ & $\begin{array}{c}36.67^{\mathrm{c}} \pm \\
1.060\end{array}$ & $\begin{array}{l}43.91^{\mathrm{b}} \pm \\
1.703\end{array}$ & $55.73^{\mathrm{a}} \pm 1.211$ \\
\hline ADLI & $\begin{array}{c}12.62^{\mathrm{d}} \pm \\
0.848\end{array}$ & $\begin{array}{c}20.56^{\mathrm{c}} \pm \\
1.295\end{array}$ & $\begin{array}{c}30.62^{\mathrm{b}} \pm \\
1.375\end{array}$ & $39.60^{\mathrm{a}} \pm 0.193$ \\
\hline
\end{tabular}

The mean values followed by different letter are significantly different $(\mathrm{P}<0.05)$

Diet $\mathrm{A}=$ Urea treatment $0 \% \quad$ Diet $\mathrm{B}=$ Urea treatment $1 \%$ Diet $\mathrm{C}=$ Urea treatment $2 \% \quad$ Diet $\mathrm{D}=$ Urea treatment $2 \%+\mathrm{SBM} 2$

The mean values of the OMI of the diets $\mathrm{A}, \mathrm{B}, \mathrm{C}$ and $\mathrm{D}$ were $50.7,52.7,57.7$ and 63.1 (gm/day) respectively. The OMI of the rabbits feeding experimental diets B, C and D were significantly affected while groups of rabbits receiving rations $\mathrm{A}$ and $\mathrm{B}$ were non significantly affected. The OMI of the rabbits feeding diet $\mathrm{D}$ was highest $(63.1 \mathrm{gm} /$ day).However rabbits feeding on diet $\mathrm{A}$ were the lowest organic matter intake $(48.7 \mathrm{gm} /$ day) among the other groups of rabbits. The CPI in grams for diets A, B, C and D were 4.95, 6.91, 8.87 and 13.14 (gm/day) correspondingly. The crude protein intake of experimental rations $\mathrm{B}, \mathrm{C}$ and $\mathrm{D}$ were significantly different among the four tested rations while the rabbits receiving diets $\mathrm{A}$ and $\mathrm{B}$ were non significant. The related 
trend was observed in the crude protein intake that CPI was highest (13.14 gm/day) for rabbits feeding experimental diet D. However it was lowest (6.91gm/day) in the rabbits receiving diet A.

The data in table 3.1 showed that the total dry matter intake of the experimental ration containing different level of urea and SBM treated groundnut shells increase the daily feed intake as dry matter, crude protein and organic matter (gm/rabbit/day). The reason was that urea and SBM treated groundnut shells had increased the palatability of experimental ration of rabbits. The similar result was observed by M. S. Kraidees et al. Who stated that the improvement in the straw digestibility and palatability was due to urea treatment of straw?

The current result showed that the ether extract intake (12.77 gm/day), nitrogen free extract intake (11.143 gm/day) and daily ash intake (10.97 gm/day) in growing rabbits receiving diet $\mathrm{D}$ was highest as compare to other three groups of rabbits while it was lowest in rabbits feeding $\operatorname{diet} \mathrm{A}$.

In the current experiment, it was clearly observed in table 3.1 that the Neutral Detergent Fiber, Acid Detergent Fiber and Acid Detergent Lignin intake 64.87, 55.73 and 39.60 (gm/day) respectively was maximum in group of rabbits that consumed the experimental diet D while it was minimum in rabbit's group that received the experimental diet A. Although intake of Neutral Detergent Fiber, Acid Detergent Fiber and Acid Detergent Lignin in experimental rabbits feeding rations A, B, C and D were significantly affected as shown in table 3.1.

The data revealed that the experimental ration containing different level of urea and soybean meal treated groundnut shells had an effect on the hunger of the growing rabbit's as well as the intake of the nutrient's for the long time of utilization. The main reason for increased intake in growing rabbits was due to addition of plant urea's enzyme at the time of urea (ammonia) treatment acts on groundnut shells by breaking down ester linkages between cell wall polymers. Using $2 \%$ soybean meal as a source of urea's enzyme with urea treated groundnut shells helped to reduce the crude fiber percent in experimental diets by increasing cell wall porosity, which makes polysaccharides more available to enzymatic hydrolysis. The present result are well corresponded with the finding of Ahmed et al. Who observed that the animal receiving different level of urea and soybean meal treatment in their diet consumed more dry matter than control one.

\section{In vivo digestibility of nutrients}

Results of the in vivo nutrients digestibility of the four tested diets are given in the Table 3.2. The mean values of the DMD for the diets A, B, C and D were 53.26, 55.41, 62.90 and 70.91 percent respectively. The results described that apparent digestibility of dry matter of diets B, C and D were significantly different $(\mathrm{P}<0.05)$. However rabbits receiving ration $A$ and $B$ were non significant. The digestibility coefficient of the rabbits feeding on diet $\mathrm{D}$ was observed high (70.91\%) among the four tested rations. The OM digestibility mean values of the four diets $A, B, C$ and $D$ were $71.82,71.83,75.80$ and 78.89 percent respectively. The apparent digestibility of the organic matter in group of rabbits receiving diet $\mathrm{D}$ was seen maximum than the other three diets. The OM digestibility of the rations $\mathrm{B}, \mathrm{C}$ and $\mathrm{D}$ were significant with

Table 3.2: In vivo nutrient digestibility (Mean \pm SE) used in the experimental ration

\begin{tabular}{|c|c|c|c|c|}
\hline \multirow{3}{*}{ Parameters } & \multicolumn{4}{|c|}{ Diets } \\
\hline & $\mathbf{A}$ & B & C & D \\
\hline & UR- $0 \%$ & UR-1\% & UR-2\% & UR-2\% + SBM-2\% \\
\hline DMD & $53.26^{c} \pm 1.377$ & $55.41^{c} \pm 1.199$ & $62.90^{\mathrm{b}} \pm 1.240$ & $70.91^{\mathrm{a}} \pm 1.083$ \\
\hline OMD & $71.82^{c} \pm 0.679$ & $71.83^{c} \pm 0.464$ & $75.80^{\mathrm{b}} \pm 0.941$ & $78.89^{a} \pm 0.410$ \\
\hline CPD & $62.85^{c} \pm 0.991$ & $68.95^{c} \pm 0.833$ & $73.56^{b} \pm 0.988$ & $80.63^{\mathrm{a}} \pm 1.152$ \\
\hline EED & $79.27^{\mathrm{b}} \pm 1.067$ & $79.48^{\mathrm{b}} \pm 0.201$ & $80.05^{b} \pm 1.857$ & $85.32^{a} \pm 0.491$ \\
\hline NFED & $66.88^{c} \pm 1.405$ & $69.72^{\mathrm{bc}} \pm 1.412$ & $71.61^{\mathrm{b}} \pm 1.439$ & $81.18^{a} \pm 0.991$ \\
\hline Ash D & $68.91^{c} \pm 0.122$ & $71.66^{\mathrm{b}} \pm 0.473$ & $71.78^{\mathrm{b}} \pm 1.139$ & $73.96^{a} \pm 0.292$ \\
\hline NDFD & $44.94^{\mathrm{d}} \pm 0.694$ & $51.14^{c} \pm 0.936$ & $61.82^{b} \pm 1.476$ & $72.12^{\mathrm{a}} \pm 1.034$ \\
\hline ADFD & $35.37^{\mathrm{d}} \pm 0.964$ & $40.42^{\mathrm{c}} \pm 1.144$ & $44.56^{\mathrm{b}} \pm 1.455$ & $58.13^{\mathrm{a}} \pm 0.859$ \\
\hline ADLD & $21.37^{\mathrm{d}} \pm 1.493$ & $26.81^{\mathrm{c}} \pm 1.684$ & $34.18^{\mathrm{b}} \pm 0.951$ & $42.10^{\mathrm{a}} \pm 1.169$ \\
\hline
\end{tabular}

The mean values followed by different letter are significantly different $(\mathrm{P}<0.05)$ 
average means of $71.83,75.80$ and 78.89 percent respectively Although ration $\mathrm{A}$ and $\mathrm{B}$ were non significantly affected. The $\mathrm{CP}$ digestibility mean values of the diets $\mathrm{A}, \mathrm{B}, \mathrm{C}$ and $\mathrm{D}$ were 62.85 , $68.95,73.56$ and $80.63 \%$ correspondingly. The digestibility of crude protein was seen high in the diet D (80.63\%). While in the diet A $(62.85 \%)$ and diet B (68.95\%) the CP digestibility was observed minimum. Similarly the $\mathrm{CP}$ digestibility was significantly different among the experimental diets $\mathrm{B}, \mathrm{C}$ and $\mathrm{D}$ while diet $A$ and $B$ were non significant of the treated diets. The present study of the experiment revealed that dry matter (DM), organic matter (OM) and crude protein (CP) digestibility coefficient was brilliant in ration $\mathrm{D}$ while digestibility coefficient was seen minimum in the diets A and B. Similarly ether extract digestibility (85.32 \%),nitrogen free extract digestibility (81.18\%) and ash digestibility $(73.96 \%)$ was maximum in group of rabbits feeding diet $\mathrm{D}$ and it was minimum in rabbits receiving $\operatorname{diet} \mathrm{A}$ in the four tested diets.

In table 3.2, the excellent digestibility coefficient of Neutral Detergent Fiber, Acid Detergent Fiber and Acid Detergent Lignin were $72.12,58.13$ and 42.10 percent respectively in rabbits receiving diets $\mathrm{D}$ while it was minimum $(44.94,35.37$ and $21.37 \%$ respectively) in group of rabbits feeding diet A. However digestibility coefficient of Neutral Detergent Fiber, Acid Detergent Fiber and Acid Detergent Lignin for rabbits feeding diets A, B, C and D were significantly affected.

It was proved from study that the nutrient digestibility were higher in group of rabbits receiving urea treated cowpea husk based diet and urea treated straw because some lignocelluloses linkages were broken down by urea which allow more intensive microbial fermentation [14].

In the current study, the enhancement of digestibility may be due to the capability of the ammonia released from urea to weaken the lignified outer walls, which allow ceacal microorganisms for better penetration to produce more effective liberation and fermentation of the nutrients and also such ammonia soften the lignin layer which speed up the fermentation process of the nutrients by allowing the micro flora to penetrate easily $[15,16]$.

The digestibility coefficient was seen maximum in the rabbit's group that consumed the experimental diet D containing urea and soybean meal treated groundnut shells. Because with urea solution the addition of soybean meal may result in better digestibility by hydrolyzing urea. According to Ahmad et al. Which stated that the apparent digestibility of nutrients was maximum when soybean meal were used as a source of urea's with urea treated rice straw.

The current study correspond to the finding of who revealed that during urea treatment the use of $3.5 \%$ chick pea seed meal as urea's source may helped in urea hydrolyzation which resulted in better nutrient digestibility by the animals [17].

\section{Nitrogen Retention}

The results of the retention of nitrogen in the body of growing rabbits were presented in the Table 3.3. The mean values of the nitrogen retention for the growing rabbits receiving rations A, B, C and D were 1.13, 1.36, 1.62 and 2.00 (gm/day) respectively. The retention of nitrogen contents was observed more $(2.00 \mathrm{gm} /$ day) in the group of rabbits receiving diet D. However group of rabbits receiving diet $\mathrm{A}$ had the lowest value $(1.13 \mathrm{gm} /$ day) of retained nitrogen. The current result showed that the nitrogen retention in growing rabbits receiving $\operatorname{diet} \mathrm{A}, \mathrm{B}, \mathrm{C}$ and $\mathrm{D}$ were significantly affected $(\mathrm{P}<0.05)$ by the treated diet.

\begin{tabular}{|c|c|c|c|c|}
\hline \multirow{3}{*}{ Parameter } & \multicolumn{4}{|c|}{ Diets } \\
\hline & A & B & C & D \\
\hline & UR- 0\% & UR-1\% & UR-2\% & $\begin{array}{c}\text { UR- } \\
2 \%+\text { SBM-2\% }\end{array}$ \\
\hline $\mathrm{N}$ intake & $1.71^{\mathrm{c}} \pm 0.026$ & $1.87^{\mathrm{c}} \pm 1.873$ & $2.10^{\mathrm{b}} \pm 0.064$ & $2.45^{\mathrm{a}} \pm 0.036$ \\
\hline $\begin{array}{c}N \text { excreted } \\
(F+U)\end{array}$ & $0.57^{a} \pm 0.021$ & $0.51^{\mathrm{ab}} \pm 0.040$ & $0.47^{b} \pm 0.031$ & $0.45^{b} \pm 0.013$ \\
\hline $\mathrm{N}$ retained & $1.13^{\mathrm{d}} \pm 0.020$ & $1.36^{c} \pm 0.076$ & $1.62^{b} \pm 0.094$ & $2.00^{\mathrm{a}} \pm 0.032$ \\
\hline
\end{tabular}

The mean values followed by different letter are significantly different $(\mathrm{P}<0.05)$

Better consumption of nitrogen in groups of rabbits receiving urea treated groundnut shells based diets may have greater ammonia absorption which results from urea hydrolysis from the rabbit's digestive tracts. Though the nitrogen balance was positive in the four groups. Retention of nitrogen was higher in groups that consumed urea treated groundnut shells based diets, suggesting that rabbits were capable to utilize urea nitrogen. The result were supported by which stated that the nitrogen retention are higher in those group of rabbits receiving urea treated cowpea husk based diet which show that rabbit can utilize urea nitrogen. Among the four groups of rabbits the nitrogen retention was observed maximum in the rabbits group receiving experimental diet $\mathrm{D}$. Because in the experimental diet D, the soybean meal act as urease source which cause better urea hydrolysis and enhanced ammonia absorption in the digestive tract of rabbits receiving experimental diet D. Our results are according to that of Kraidees where he described that the addition of soybean meal significantly increased $\mathrm{N}$ digestibility and $\mathrm{N}$ retention among the four tested diets.

\section{Body weight gain and feed conversion ratio}

The data related to the daily weight gain in grams and FCR in the experimental animals feeding different diets presented in the Table 3.4. The daily body weight gain mean values of the experimental rabbits consuming diets A,B, C and D were 4.03,4.19, 4.39 and $5.12 \mathrm{gm} / \mathrm{rabbit} /$ day respectively. The current study result demonstrate that the mean values of daily body weight gain of diets $B, C$ and $D$ were statistically significant $(P<0.05)$ while that was observed non significant in groups of rabbits receiving diets $\mathrm{A}$ and $\mathrm{B}$. The group of rabbits receiving experimental diet $\mathrm{D}$ was excellent in daily body weight gain. 


\begin{tabular}{|c|c|c|c|c|}
\hline \multirow{3}{*}{ Parameters } & \multicolumn{4}{|c|}{ Diets } \\
\hline & $\mathbf{A}$ & B & C & D \\
\hline & UR- 0\% & UR-1\% & UR-2\% & $\begin{array}{c}\text { UR-2\% } \\
+ \text { SBM- } \\
2 \%\end{array}$ \\
\hline $\begin{array}{c}\text { Initial body } \\
\text { weight(gm/day) }\end{array}$ & $\begin{array}{c}1103.7^{\mathrm{ab}} \pm \\
12.07\end{array}$ & $\begin{array}{c}1150.4^{\mathrm{a}} \pm \\
10.41\end{array}$ & $\begin{array}{c}1067.7^{\mathrm{b}} \pm \\
9.52\end{array}$ & $\begin{array}{l}1165.6^{\mathrm{a}} \\
\pm 11.99\end{array}$ \\
\hline $\begin{array}{c}\text { Final weight } \\
\text { (gm) }\end{array}$ & $\begin{array}{c}1332.1^{\mathrm{b}} \pm \\
11.20\end{array}$ & $\begin{array}{c}1402.3^{\mathrm{ab}} \pm \\
13.12\end{array}$ & $\begin{array}{c}1331.2^{\mathrm{b}} \pm \\
8.58\end{array}$ & $\begin{array}{l}1473.0^{\mathrm{a}} \\
\pm 10.86\end{array}$ \\
\hline Difference(gm) & $\begin{array}{c}249.40^{c} \pm \\
3.192\end{array}$ & $\begin{array}{c}251.91^{\mathrm{c}} \pm \\
3.131\end{array}$ & $\begin{array}{c}263.52^{\mathrm{b}} \pm \\
3.152\end{array}$ & $\begin{array}{l}307.42^{\mathrm{a}} \\
\pm 4.561\end{array}$ \\
\hline $\begin{array}{l}\text { Body weight ( } \mathrm{g} / \\
\text { day) }\end{array}$ & $4.03^{c} \pm 0.053$ & $\begin{array}{c}4.19^{c} \pm \\
0.052\end{array}$ & $\begin{array}{c}4.39^{\mathrm{b}} \pm \\
0.051\end{array}$ & $\begin{array}{c}5.12^{\mathrm{a}} \pm \\
0.076\end{array}$ \\
\hline FCR & $5.03^{\mathrm{a}} \pm 0.061$ & $\begin{array}{c}4.35^{\mathrm{b}} \pm \\
0.081\end{array}$ & $\begin{array}{c}4.19^{\mathrm{b}} \pm \\
0.055\end{array}$ & $\begin{array}{c}3.11^{\mathrm{c}} \pm \\
0.072\end{array}$ \\
\hline
\end{tabular}

The mean values followed by different letter are significantly different $(P<0.05)$

In the Table 3.4, the mean values of the FCR of rabbit receiving ration $\mathrm{A}, \mathrm{B}, \mathrm{C}$ and $\mathrm{D}$ were $5.03,4.35,4.19$ and 3.11 respectively. The efficient FCR (3.11) was seen in the rabbits group that consumed experimental diet D. However groups of growing rabbits consuming experimental diet $\mathrm{B}$ and $\mathrm{C}$ were non significant in FCR. As a whole FCR of the experimental diets D was better than the FCR of the group of rabbits feeding on control diet A.

The improvement in body weight gain of the group of rabbits receiving diet Das compared to the group of rabbits receiving diet A may be due to the fact that the rabbits of these group get more protein when $2 \%$ soybean meal were added at the time of urea treatment [18].

The urea and soybean meal treated groundnut shells in the experimental diet enhanced the FCR of dry matter, crude protein, organic matter and total digestible nutrient because soybean urea's quickly hydrolyzes the urea which enhancing microbial multiplication. Ultimately there would be more available amino acid for host animals for body growth as compared to those animals which fed urea treated straw without any external urea's source [17].

\section{Economics of the feed}

The profitability mean values of the experimental rabbit's were presented in the Table 3.5. The profit mean values for the groups of rabbits feeding on $\operatorname{diet}$ A, B, C and D were Rs. $22.37,29.03,47.96$ and 63.92 respectively. The maximum total income and profit of Rs. 63.92 was calculated for experimental animals feeding on diet $\mathrm{D}$ than the other groups of experimental diets. However the poor profitability value of Rs. 22.37 was recorded for the group of rabbits fed on diet A. Although cost of feed per rabbit cost was less (Rs: 12.92) in rabbits feeding diet D and was more (Rs: 34.72 ) for the growing rabbits receiving $\operatorname{diet} \mathrm{A}$.

Table 3.5: Effect of different level of urea and SBM (Mean \pm SE) treatment on experimental ration profitability

\begin{tabular}{|c|c|c|c|c|}
\hline \multirow{2}{*}{ Parameter } & \multicolumn{4}{|c|}{ Diets } \\
\cline { 2 - 5 } & A & B & C & D \\
\cline { 2 - 5 } & UR- 0\% & UR -1 \% & UR - 2\% & $\begin{array}{c}\text { UR-2\% + } \\
\text { SBM-2\% }\end{array}$ \\
\hline Total wt. & $228.40^{\mathrm{d}} \pm$ & $251.91^{\mathrm{c}} \pm$ & $263.52^{\mathrm{b}} \pm$ & $307.42 \pm$ \\
gain (gm) & 3.192 & 3.131 & 3.152 & 4.561 \\
\hline Feed cost/ & $34.72^{\mathrm{a}} \pm 0.879$ & $33.94^{\mathrm{a}} \pm$ & $17.91^{\mathrm{b}} \pm$ & $12.92^{\mathrm{c}} \pm$ \\
rabbit & & 0.866 & 0.196 & 0.205 \\
\hline \multirow{2}{*}{ Total sale } & $57.09^{\mathrm{d}} \pm 0.799$ & $62.97^{\mathrm{c}} \pm$ & $65.87^{\mathrm{b}} \pm$ & $76.85^{\mathrm{a}} \pm$ \\
\hline \multirow{2}{*}{ Profit } & $22.37^{\mathrm{d}} \pm 1.601$ & 0.783 & 0.789 & 1.142 \\
\hline & & $29.03^{\mathrm{c}} \pm$ & $47.96^{\mathrm{b}} \pm$ & $63.92^{\mathrm{a}} \pm$ \\
\hline
\end{tabular}

The mean values followed by different letter are significantly different $(P<0.05)$

In the current result the economic feed efficiency of the experimental diet was calculated on basis of Rs. FCR. According to Ntiranyibagira Emmenuel et al who stated that feed efficiencies were actually enhanced with different level of urea up to an optimum level. Once the urea is exceeded that level in diet, a considerable depression of intake, digestibility and feed efficiency occurred in animals.

\section{Conclusion}

The use of urea and soybean meal treated groundnut shells in the rabbit ration enhanced nutritive value and apparent digestibility coefficient of the nutrients of the experimental diets and has maximum proportion of nitrogen retention in the body of growing rabbits as compared to the control group of rabbits. The rabbits feeding diet containing urea and soybean meal treated groundnut shells were excellent in relative economic efficiency and lowered value of feed cost per rabbit. Groundnut shells has shown to be good substrate when treated with appropriate level of urea and urease which leads to an effective and economic way to utilize the unused crop residue.

\section{References}

1. Bamgbose AM, Abimbola M, Olayemi WA, Owofowora AO, Oso AO, AT Ojo. Performance of weaner rabbits fed supplemented tridax procumbens Pro. 7th Anim Conf. Anim Sci Ass of Nig. (ASAN) September 16-19. University of Agric. Abeokuta Nig. 2002.

2. Arijeniwa A, Otaikhian SO, Imaseum JA. Performance of weaner rabbits fed poultry grower mash supplemented with different grass legume rations. Proceedings of 5th Annual Conference of Anim Sci Ass Nig. (ASAN). 103-105. 2000.

3. Ozung PO, Bittoand II, Ikurior SA. Carcass yield, gut morphology, reproductive tract morphometry and some biochemical characteristics of serum in female rabbits fed cassava peel meal based diets. Cont j Anim. Vet Res. 2011;3:22-32 
4. Montagne L, pluske JR, Hampson DJ. A review of interaction between dietary fiber and the intestinal mucosa and their consequences in digestive health in young non-ruminant animals. Animal feed. Sci. technology. 2003;108:95-117.

5. Vancov T, McIntosh S. Alkali pretreatment of cereal crops residues for second generation biofuels. Energy Fuels. 2011;25:2754-2763.

6. Xiccato G, Trocino A. Feed and energy intake in rabbits and consequences on farm global efficiency. In Proc.: 6th International Conference on Rabbit Production in Hot Climates, Egypt. 2010;1-18.

7. Gómez-Conde MS, Pérez de Rozas A, Badiola I, Pérez-Alba L, De Blas JC, Carabaño R, García J. Effect of neutral detergent soluble fibre on digestion, Intestinal microbiota and performance in twenty five day old weaned rabbits. Livest. Sci. 2009;125:192-198.

8. Gidenne T. Recent advance in rabbit nutrition: emphasis on fibre requirements. World rabbit Sci. 2000;8(1):23-32.

9. Fortun-Lamothe L, Gidenne T. Besoinsnutritionnels du lapereau et stratégiesd'alimentationautour du sevrage. INRA Prod. Anim. 2003;16:39-47.

10. Adua MM, Alu SE, Thani RJ, Abubakar HT, Matthew UD. Effect of different alkali-treated groundnut (Arachis hypogea) shell meal on blood parameters and meat yield of broiler finisher chickens. Scholarly J. Agri. Sci. 2012;2(9):224-230.

11.AOAC. 2007. Method 2004-07. Association of official analytical chemists, Washington, DC.
12. Van Soest PJ, Robertson JB, Lewis BA. Methods for dietary fiber, neutral detergent fiber and non-starch polysaccharides in relation to animal nutrition. J Dairy Sci. 1991;74(10):3583-3597.

13. Goering, HK, Van Soest PJ. Forage fiber analyses (Apparatus, Reagents, Procedures, and Some Applications). USDA Agricultural research service. Agri. Handbook No. 379.1991.

14. Kraidees MS. Influence of Urea Treatment and Soybean Meal (Urease) Addition on the Utilization of Wheat Straw by Sheep. Asian-Aust. J. Anim. Sci. 2005;18(7):957-965.

15. Akter M, Khan MJ, Akbar MA, Asaduzzaman M. Improving quality of rice straw through treatment with urea and midden soil for large animals. Bang. J. Anim. Sci. 2013;42(1):29-34.

16. Ntiranyibagira E, Patil NV, Bhagwat SR, Lateef A, Kang X, Hongnan L. Effects of different levels of urea supplementation on nutrient intake and growth performance in growing camels fed roughage based complete pellet diets. J Ani Nut. 2015;1(4):356-361.

17. Hossain MM, Khan MJ, Akbar MA. Nutrient digestibility and growth of local bull calves as affected by feeding urea and urease enzyme sources treated rice straw. Bang. J. Anim. Sci. 2010;39(1-2):97-105.

18. Ahmed S, Khan MJ, Shahjalal M, Islam KMS. Effects of Feeding Urea and Soybean Meal-Treated Rice Straw on Digestibility of Feed Nutrients and Growth Performance of Bull Calves. Asian-Aust. J. Anim. Sci. 2002;15(4):522-527. 